\title{
Follow-up care of rare diseases in odontology: a public health issue
}

\author{
S Toupenay ${ }^{1,2^{*}}$, M de la Dure ${ }^{1,3}, \mathrm{~N}$ Razanamihaja ${ }^{1,2}$, A Berdal ${ }^{2,3}$, M-L Boy-Lefèvre ${ }^{1,2}$ \\ From 5th International Conference on Ectodermal Dysplasia (ED2012) \\ Erlangen, Germany. 1-3 June 2012
}

This study aims at providing new data relating to rare diseases with or without bucco-dental component. A national investigation based on a questionnaire has been carried out in France and a clinical study has been completed with the patients consulting the national centre of rare malformations of the face and the buccal cavity, in particular oligodontia.

The results revealed a difficult and complex course of care for all the patients suffering from rare diseases. The oral health quality is not linked to the severity of the bucco-dental component. An unfavorable medico-economic impact has been noted in the treatment of numeric anomalies of teeth, including oligodontia. Proposals have been raised to improve the follow-up care of these patients on the basis of the current evolution of health policy.

\footnotetext{
Author details

'Department of Public Health, Dental Faculty, University of Paris Diderot, France. ${ }^{2}$ Reference Centre of Rare Diseases of Face and Buccal Cavity, Paris Hospitals, France. ${ }^{3}$ INSERM Cordeliers Biomedical Research Centre, Paris, France.
}

Published: 25 May 2012

Submit your next manuscript to BioMed Central and take full advantage of:

- Convenient online submission

- Thorough peer review

- No space constraints or color figure charges

- Immediate publication on acceptance

- Inclusion in PubMed, CAS, Scopus and Google Scholar

- Research which is freely available for redistribution 